\title{
Salix xmarchettii (Salicaceae), a new nothospecies from the Apuan Alps (Northern Tuscany, Central Italy)
}

\author{
Marco Merli \& Fabrizio Martini
}

\begin{abstract}
MERLI, M. \& F. MARTINI (2017). Salix ×marchettii (Salicaceae), a new nothospecies from the Apuan Alps (Northern Tuscany, Central Italy). Candollea 72: 339-343. In English, English abstract. DOI: http://dx.doi.org/10.15553/c2017v722a11

A new nothospecies, Salix ×marchettii M. Merli \& F. Mart. (Salix crataegifolia Bertol. × Salix eleagnos Scop. subsp. eleagnos) (Salicaceae), is described from the Apuan Alps. This new nothotaxon grows on screes between 1010 and $1105 \mathrm{~m}$. The main morphological characters which distinguish Salix $\times$ marchettii are the indumentum with mixed, silky and tomentose trichomes on the young twigs; the leaf shape, elliptic-oblong or oblanceolate-oblong to narrowly oblanceolate; the leaf margin, which may vary from flat to weakly revolute in the same specimen; the male catkins, cylindrical and arcuate-pendant, which have flowers with connate filaments for at least half their length or more.
\end{abstract}

\section{Keywords}

SALICACEAE - Salix - Taxonomy - New nothospecies - Apuan Alps - Central Italy

\footnotetext{
Addresses of the authors :

MM: V. dei Caputei 7, 38070 Sclemo di Stenico (Trento), Italy. E-mail: marco.0671@alice.it 


\section{Introduction}

Natural hybridization within the genus Salix L. (Salicaceae) is relatively common and is likely to involve about $5 \%$ of the individuals in a population according to estimates by Neumann (1981). Willows, however, despite possessing inherently high capacity to cross even among taxonomically very distant taxa (e.g. between fruticose chamaephytes of Salix sect. Chamaetia Dumort. and nanophanerophytes of Salix sect. Arbuscella Ser.: Salix xganderi Huter ex K. Richt. = S. reticulata L. $\times$ S. waldsteiniana Willd.), do not form hybrids everywhere, but only under specific circumstances. According to SKvORTsov (1999), the phenomenon would seem to be favoured by phylogenetic relationships among species and individual needs of adaptation to climatic or edaphic disturbances, typical of naturally unstable environments (i.e. moraines, screes) or degraded by human action (i.e. disused quarries, escarpments, etc.). On the other hand, within stable populations, the presence of hybrids is a substantially rare occurrence, despite the contiguity between individuals of different species. For further details see also Martini \& Paiero (1988, in press), LAUTENSCHLAger (1989), Hörandl et al. (2002) and Gramlich \& HöRANDL (2016).

In addition, the attribution of a specimen to a hybrid form may often be due to inadequate knowledge of the specific variability which, in many cases, may be considerable, as in critical groups such as S. nigricans $\mathrm{Sm}$. or S. caprea L.

Therefore, the morphological study of Salix hybrids requires extensive comparison of material, taking into consideration the variability of their respective parents. The diacritical characteristics of hybrids are expressed, in most cases, in the shape of the leaf blade and in the type of indumentum.

\section{Materials and methods}

The morphological and morphometric analysis was performed both on fresh material and on herbarium specimens deposited in ROV, MFU (also containing specimens of the herbarium Marchetti, Massa), TSB (acronyms follow Index HerbarioRUM, 2017) and of the private collections of MM [herb. Merli] and C. Argenti (Belluno). The taxa investigated (in brackets the number of studied specimens) were: $S$. crataegifolia Bertol. (20), S. eleagnos subsp. eleagnos (30) and the new hybrid (12). A Leica EZ4 HD microscope was used for observations and details of indumentum and catkins and for taking photographs. The scientific nomenclature follows Conti et al. (2005).

\section{Taxonomy}

Salix $\times$ marchettii M. Merli \& F. Mart., nothospec. nova (Fig. 1, 2).

Typus: ITALY. Reg. Tuscany: Prov. Massa-Carrara, Apuan Alps, NW slope of M. Pelato along the road from Pian della Fioba to the M. Pelato tunnel, 1010 m, 15.V.2016, M. Merli s.n. (holo- : FI!; iso- : G!, herb. Merli!, ROV!).

Salix $\times$ marchettii shows intermediate characters between S. crataegifolia and S. eleagnos subsp. eleagnos, but differs from both by the young twigs' indumentum (mixed silky and tomentose trichomes), the presence in the same specimen of both elliptic-oblong or oblanceolate-oblong (S. crataegifolia) and narrowly oblanceolate (S. eleagnos subsp. eleagnos) leaves.

Shrub (40-)60-120(-140) cm tall, twigs ascending or procumbent, with dark grey to blackish bark; young twigs with blackish indumentum with mixed, silky and tomentose trichomes, becoming glabrous or nearly so at maturity. Leaves elliptic-oblong or oblanceolate-oblong to narrowly oblanceolate, (3.5-)4-8(-9.5) cm, 3-6 times as long as wide, with flat to weakly revolute and toothed margin, with teeth thickened in the distal half; upper side tomentose in young leaves, finally glabrous; lower side silky in young leaves, later only next to the midrib or glabrous. Lateral veins (9-)17-25 pairs, reticulate and weakly prominent only beneath. Petiole 3-8.5 mm long. Stipules absent or minute, triangular. Male catkins cylindrical, arcuate-pendant, $1.5-3(4) \mathrm{cm}$ long, about $0.5 \mathrm{~cm}$ in diameter; female catkins initially arcuate-pendant, then suberect, 1.5$3(4) \mathrm{cm}$ long, $0.5-0.8 \mathrm{~cm}$ large; pedicel up to $1 \mathrm{~cm}$ long. Floral bracts elliptic-rounded, apex truncate, brown-reddish. Male and female flowers with 1 nectary. Filaments connate for at least half their length, glabrous. Capsule 3.5-4 mm, glabrous, usually sterile; pedicel short.

Phenology. - Catkins appear with the leaves in May-June.

Etymology. - The new hybrid is dedicated to Prof. Dino Marchetti (Massa), researcher and expert on the flora of the Apuan Alps.

Notes. - The diacritical characters which distinguish S. $\times$ marchettii from its parents are summarized in Table 1 . In $S . \times$ marchettii the young twig indumentum shows mixed trichomes, silky (typical of $S$. crataegifolia) and matted (tomentose), characteristic of S. eleagnos (Fig. 2A). Size and shape of the leaf, elliptic-oblong or oblanceolate-oblong to narrowly oblanceolate, are also intermediate between those of the parents, as well as the margin, which may vary from flat (S. crataegifolia) to weakly revolute (S. eleagnos subsp. eleagnos) in the same specimen. Also the number of lateral veins, which varies between (9-)17 and 25 pairs, is intermediate 


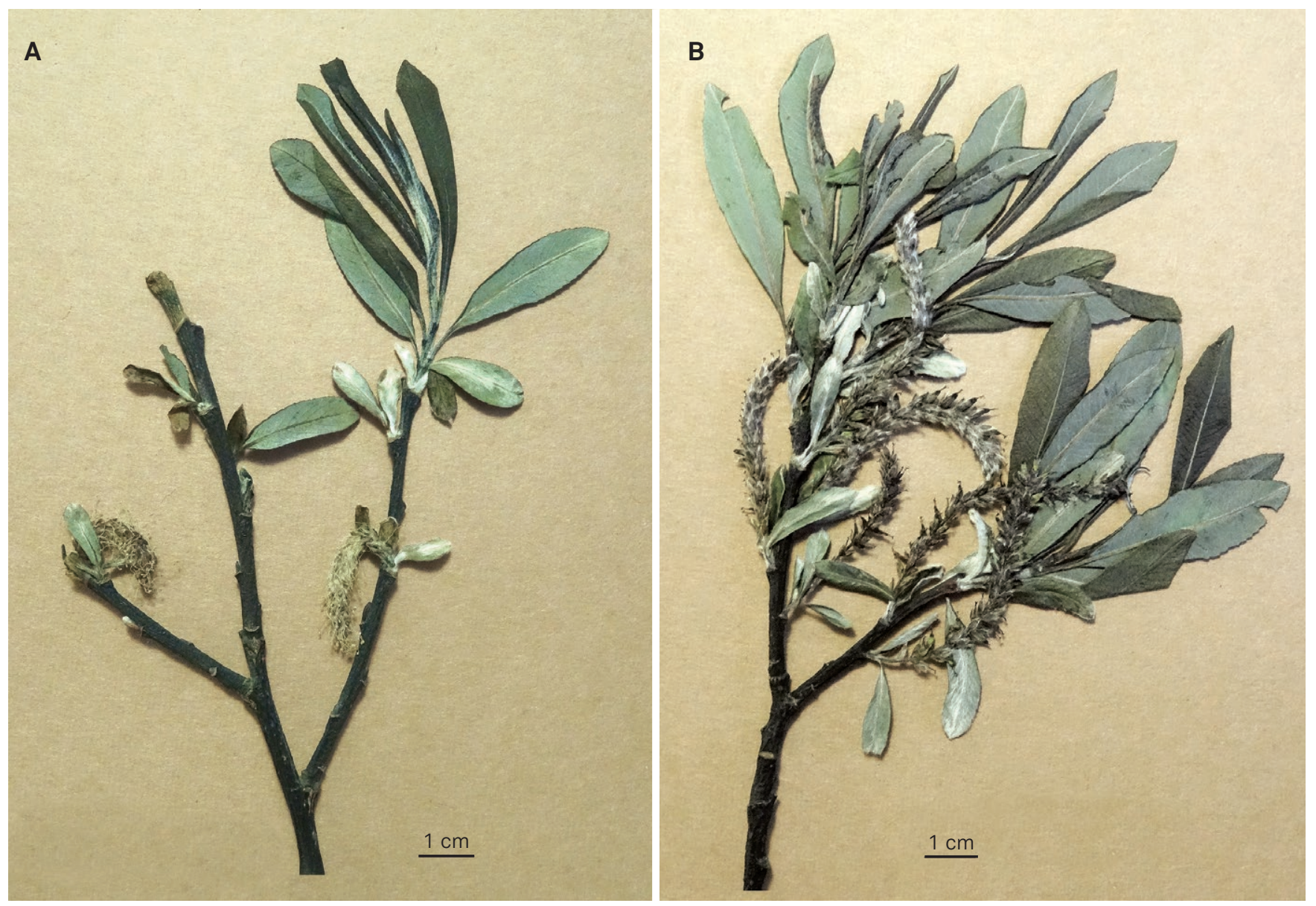

Fig. 1. - Salix xmarchettii M. Merli \& F. Mart. A. Male specimen. B. Female specimen.

between those of the parents, but in $S . \times$ marchettii the veins appear prominent only below, as in S. eleagnos. The silky indumentum of the lower leaf blade and petiole recalls mainly $S$. crataegifolia and, as in the latter, is very dense in immature leaves. This indumentum persists on leaves when mature only on the midrib or is completely deciduous. The leaf petiole is usually more developed than in $S$. eleagnos. The heritage of $S$. eleagnos appears better defined in male catkins, whose sizes are intermediate between those of the parents, but the filaments are connate, as in S. eleagnos, for at least half their length or more (Fig. 2B). The development of female catkins recalls, in form and posture, that of $S$. crataegifolia, but, in the observations so far, the capsules were sterile. The floral bracts are similar in shape to those of $S$. crataegifolia, usually completely brownish, at first silky then glabrous or nearly so.

Salix eleagnos belongs to the central-southeastern European chorotype (Jalas \& Suominen, 1976). Its intraspecific variability is restricted to two subspecies, $S$. subsp. eleagnos and $S$. subsp. angustifolia (Cariot \& St.-Lag.) Rech. f., based on leaf morphology (shape, ratio length/width and type of leaf margin). The nominal subspecies seems by far the most dominant one in Italy (Pignatti, 1982; Martini \& Paiero, 1988).

Salix crataegifolia, described by Bertoloni (1813), represents one of the most interesting willow species in Europe. The arcuate-pendant posture of the catkins, always observable in the males while in the females noticeable only until flowering, represents an ancestral character. Moreover, the morphology of the vascular bundles of the leaves, the small size of the pollen grains and low chromosome number are typical characters of this palaeoendemic species, phytogeographically isolated (Bechi et al., 1996; Garbari et al., 2007) and with a limited individual variability. For these same reasons SkvorTsov (1999) hypothesizes a link between several species of the Chinese Himalaya (S. sikkimensis Anderss., S. daltoniana Anderss.) and S. ernesti C.K. Schneider from Sichuan. Salix crataegifolia is a steno-endemic chasmophyte of the Apuan Alps, with a distribution area of only $261.6 \mathrm{~km}^{2}$, which has convinced Roma-Marzio et al. (2015) to propose its inclusion among the "Near Threatened" [NT] species. 

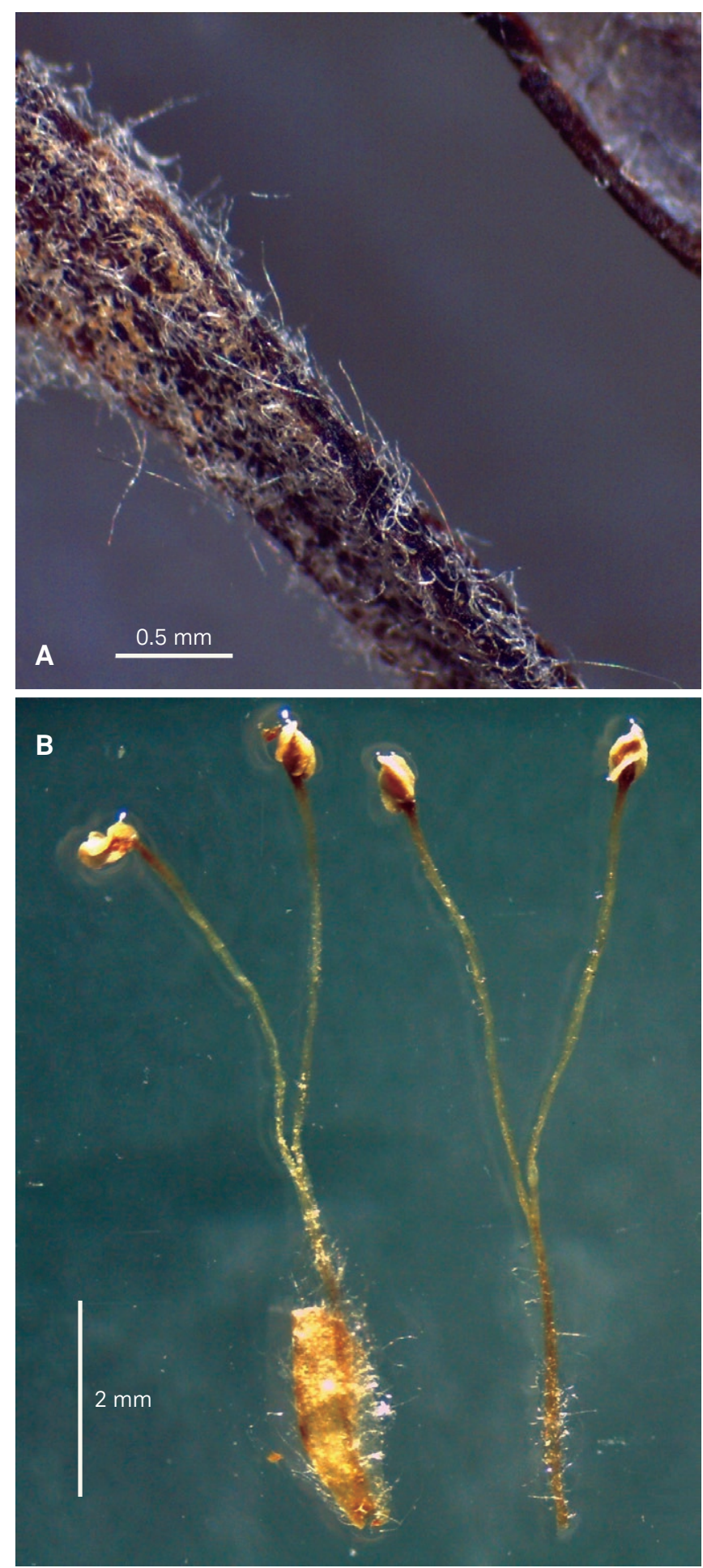

Fig. 2. - Salix $\times$ marchettii M. Merli \& F. Mart. A. Mixed indumentum on young twig: silky and matted hairs. B. Connate filaments.
Considering the above discussed features and the absence of other hybrid forms with $S$. crataegifolia as a parent, the discovery of $S$. × marchettii has generated considerable surprise. Hence, among all Salix hybrids, $S$. x marchettii represents a unique case because it is the result of a cross with $S$. crataegifolia and therefore an endemic nothospecies of the Apuan Alps. From an ecological point of view, it behaves as a genuine gravel species like S. eleagnos, while $S$. crataegifolia prefers rocks (limestone and metamorphic) and is rarely growing on gravels (Roma-Marzio et al., 2015). Salix x marchettii is known so far from a single population on the northwestern slope of M. Pelato, where, however, it is fairly widespread on the road side gravel and on the underlying rocky slope, together with $S$. crataegifolia (abundant), S. eleagnos subsp. eleagnos and $S$. apennina (more rare), S. purpurea and $S$. caprea (both occasional). According to the local distribution of the two parents as reported by Ferrarini \& Marchetti (1994) and RomaMarzio et al. (2015), it can be hypothesized that $S$. $\times$ marchettii could be sought with success at least where the parents are most common: for instance, in the Lunigiana area of the Apuan Alps (province of Massa-Carrara) and in the upper and middle valley of the river Serchio (Prov. Lucca). Finally, the discovery of $S$. $\times$ marchettii sheds new light on the capacity of hybridization of S. crataegifolia and careful research could well lead to the identification of new hybrid forms, i.e. with S. caprea and S. purpurea.

\section{Acknowledgements}

The authors thank Mrs. T. Crellin (Garda di Sonico, Brescia) and Dr. V. Casolo (University of Udine) for the revision of the text and G. Mainardis (Venzone, Udine) for the photographs of the plant.

\section{References}

Bechi, N., G. Corsi \& F. Garbari (1996). Indagini biosistematiche sulla flora apuana. IV contributo. Webbia 51:31-37.

Bertoloni, A. (1813). Salix crataegifolia. J. Bot. Appl. (Desvaux) 2: 76.

Conti, F., G. Abbate, A. Alessandrini \& C. Blasi (ed.) (2005). An annotated checklist of the Italian vascular flora. Roma.

Ferrarini, E. \& D. Marchetti (i 994). Prodromo alla flora della Regione Apuana. Parte prima (Lycopodiaceae - Leguminosae). Accad. Lunigianese Sci. G. Capellini. Studi e Documenti di Lunigiana 13.

Garbari, F., G. Bedini, M. Ansaldi \& D. Marchetti (2007). Fitogeografia apuana. Aggiornamenti biosistematici, tassonomici e corologici sulle Spermatophyta endemiche, relitte e critiche. Biogeographia 28 : 177-204. 
Table 1. - Key characters distinguishing Salix xmarchettii M. Merli \& F. Mart. from S. crataegifolia Bertol. and S. eleagnos Scop. subsp. eleagnos.

\begin{tabular}{|c|c|c|c|c|}
\hline & Characters & S. crataegifolia & S. $\times$ marchettii & S. eleagnos subsp. eleagnos \\
\hline \multirow{10}{*}{$\stackrel{\substack{\pi \\
\oplus}}{9}$} & Young twig indument & it silky with elongated straight trichomes & mixed, silky and tomentose & tomentose with curved trichomes \\
\hline & Shape & $\begin{array}{l}\text { elliptic, elliptic-lanceolate, } \\
\text { ovate-oblong }\end{array}$ & $\begin{array}{l}\text { elliptic-oblong, oblanceolate-oblong, } \\
\text { narrowly oblanceolate }\end{array}$ & linear to linear lanceolate \\
\hline & Length $[\mathrm{cm}]$ & $(2.5-) 5-8(-10)$ & $(3.5-) 4-8(-9.5)$ & $6-12(-15)$ \\
\hline & Length/width & $2-2.7$ & $3-6$ & $8-20$ \\
\hline & Margin & flat, crenate-dentate & $\begin{array}{l}\text { flat to weakly revolute, toothed, } \\
\text { with teeth thickened in the distal half }\end{array}$ & $\begin{array}{l}\text { revolute with minute glandular } \\
\text { teeth thickened in the distal half }\end{array}$ \\
\hline & Upper side & glabrous when adult & tomentose at first, ultimately glabrous & glabrous when adult \\
\hline & Lower side & $\begin{array}{l}\text { silky with elongated straight hairs } \\
\text { when later glabrous except at the side } \\
\text { of the midrib }\end{array}$ & $\begin{array}{l}\text { at first silky, later only at the side of } \\
\text { the midrib or glabrous }\end{array}$ & densely white-tomentose \\
\hline & N. lateral veins & $\begin{array}{l}\text { 8-12 pairs, reticulate and weakly } \\
\text { prominent on both sides }\end{array}$ & $\begin{array}{l}\text { (9-)17-25 pairs, reticulate and } \\
\text { weakly prominent only beneath }\end{array}$ & $\begin{array}{l}25-40 \text { pairs, reticulate and } \\
\text { prominent only beneath }\end{array}$ \\
\hline & Petiole length [mm] & $10-30$ & $3-8.5$ & up to 5 \\
\hline & Stipules & absent & absent or minute, triangular & absent or minute \\
\hline \multirow{4}{*}{ 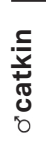 } & Posture & arcuate-pendant & arcuate-pendant & arcuate-patent \\
\hline & Length [cm] & $4-6(-8)$ & $1.5-3$ & $3-4$ \\
\hline & Width [cm] & 1.5 & 0.5 & 0.5 \\
\hline & Filament & free & connate for at least half their length & connate at base or up to the middle \\
\hline \multirow{6}{*}{ 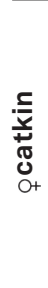 } & Posture & initially arcuate-pendant, than suberect & initially arcuate-pendant, than suberect & arcuate-patent, than suberect \\
\hline & Length $[\mathrm{cm}]$ & $5-12$ & $3.5-5.5$ & $5-6$ \\
\hline & Width $[\mathrm{cm}]$ & $0.8-1$ & $0.5-0.8$ & 0.5 \\
\hline & Floral bract shape & obovate, apex rounded-truncate & elliptic-rounded, apex truncate & obovate \\
\hline & Floral bract colour & brown-reddish & brown-reddish & $\begin{array}{c}\text { yellowish or greenish } \\
\text { (sometimes with dark apex) }\end{array}$ \\
\hline & Capsule length [mm] & 5 & $3.5-4$ & up to 5 \\
\hline
\end{tabular}

Gramlich, S. \& E. Hörandl (2016). Fitness of natural willow hybrids in a pioneer mosaic hybrid zone. Ecol. Evol. 6: 7645-7655.

INDEX HERBARIORUM (2017). Index herbariorum, a global directory of public herbaria and associated staff. New York Botanical Garden's Virtual Herbarium. [http://sweetgum.nybg.org/science/ih].

Hörandl, E., F. Florineth \& F. Hadace K (2002). Weiden in Österreich und angrenzenden Gebieten. Eigenverlag des Arbeitsbereichs Ingenieurbiologie und Landschaftsbau, Institut für Landschaftsplanung und Ingenieurbiologie, Universität für Bodenkultur, Wien.

Jalas, J. \& J. Suominen (1976). Atlas Florae Europaeae. 3. Salicaceae to Balanophoraceae. Helsinki.

Lautenschlager, E. (1989). Die Weiden der Schweiz und angrenzender Gebiete. Birkhäuser.

Martini, F. \& P. Paiero (1988). I salici d'Italia. Trieste.

Martini, F. \& P. Paiero (in press). Salix L. In: Pignatti, S. (ed.), Fl. Italia ed. 2.
Neumann, A. (1981). Die mitteleuropäischen Salix-Arten. Mitt. Forstl. Bundes-Versuchsanst. Mariabrunn. 134.

Pignatti, S. (1982). Fl. Italia vol. 1. Bologna.

Roma-Marzio, F., A. Carta, A. Di Sacco, L. Peruzzi \& G. Bedini (2015). Contributo alla conoscenza della flora vascolare endemica di Toscana ed aree contermini. 8. Salix crataegifolia (Salicaceae). Inform. Bot. Ital. 47: 205-211.

Skvortsov, A.K. (1999). Willows of Russia and adjacent countries. Taxonomical and Geographical Revision. University of Joensuu Report series 39, Finland. 